\title{
Study on Black Gram (Vigna mungo L.) Infected with Meloidogyne incognita under the Influence of Pseudomonas fluorescens, Bacillus subtilis and Urea
}

\author{
Ambreen Akhtar*, Hisamuddin, Abbasi and Rushda Sharf
}

Section of Plant Pathology and Nematology, Department of Botany, Aligarh Muslim University, Aligarh, India

\begin{abstract}
Pot studies were carried out to assess the growth and biochemical components of Vigna mungo L. cultivar 'Azad2' with the root-knot nematode and treated with two biofertilizers viz. Pseudomonas fluorescens strain $\mathrm{CHA}$, and Bacillus subtilis strain Bs-5. The plants were grown in soil at N50 and N100 doses of urea. Uninoculated untreated plants served as control. From the results, it was evident that $V$. mungo plants exhibited profused vegetative growth at N100 dose of urea as was observed in the treatment 5 . The plants of treatment 5 were inoculated with $P$. fluorescens CHAO $(20 \mathrm{ml})$. The number of nodules per plant was found increased to 14.33 per plant, total chlorophyll content by $2.91 \mathrm{mg} / \mathrm{g}$ of leaf tissue, leghaemoglobin by $3.81 \mathrm{mg} / \mathrm{g}$, and protein content in leaves and seeds by 0.83 and 0.76 $\mathrm{mg} / \mathrm{g}$, respectively, when compared with the control and the plants that received different doses of $B$. subtilis Bs- 5 in the absence of the root-knot nematode. Significant reduction in gall number (41.66) and number of nematodes per gram of root (4.66) was recorded in the treatment 5.
\end{abstract}

Keywords: Bacillus subtilis; Inorganic fertilizer; Meloidogyne incognita; Pseudomonas fluorescens; Vigna mungo

\section{Introduction}

Root-knot nematodes, the obligate sedentary endoparasites, reproduce parthenogenetically by mitotic divisions [1] and complete greater part of their life cycle inside the host plant. These are more than 2,000 plants [2-5] which comprise of all major crop plants are attached by Meloidogyne spp. The plant parasitic nematodes are responsible in causing agriculture losses amounting to $\$ 157$ billions annually [6]. Pulses contain 17 to $30 \%$ protein and upto $60 \%$ carbohydrates. They also contain reasonable amounts of niacin and thiamine but only small amounts of carotene, riboflavin and ascorbic acid [7]. The leguminous plants have the ability to fix the atmospheric nitrogen that helps in increasing the soil fertility. Vigna mungo, a nitrogen fixing leguminous plant also seems as the host of the root-knot nematodes, Meloidogyne spp. In addition to the formation of root galls, the nematodes interfere in the process of symbiotic nitrogen fixation.

Among the various pests, $M$. incognita poses a potential threat to the cultivation of pulse crops by inflicting upon severe yield losses [8-10]. Physiological and biochemical activities of the host plant are drastically affected on nematode infection [11]. Pseudomonas fluorescens strain CHAO and Bacillus subtilis strain Bs-5, the biocontrolling agents, have been reported to have direct antagonistic effects as a result of physical contact and pathogenic selectivity [12]. Pseudomonads induce host defense mechanism by synthesizing an antibiotic 2, 4diacetylphloroglucinol (DAPG) [13].

For the growth of plants, unavailability of nitrogen acts as critical limiting factor [14]. In beans, reserved food material is stored in the form of proteins, therefore, these require more nitrogen than any other nutrient [15]. Nitrogen is a constituent of proteins, enzymes, chlorophyll and growth regulators. Deficiency of nitrogen results in stunting, chlorosis, reduced branching and surface area of leaves [15].

The experiment was carried out to investigate the effects of PGPR, antagonistic to M. incognita, at different doses of nitrogen fertilizer on black gram cv. Azad-2.

\section{Materials and Methods}

The experiment was performed in glass house. Vigna mungo cv. Azad-2 was selected as test plant; the root-knot nematode, Meloidogyne incognita was selected as the test pathogen; Pseudomonas fluorescens and Bacillus subtilis as the test biocontrol agents, which were added into the soil together with the nitrogen fertilizer, urea.

\section{Plant culture}

The seeds of black gram (Vigna mungo cv. Azad-2) procured from IARI, New Delhi were surface sterilized with $\mathrm{NaOCl}$ [16] for 10 minutes and then rinsed three times with sterile water. The seeds were sown in steam sterilized soil mixture of 3:1:1, soil: sand: organic manure, in 30 $\mathrm{cm}$ clay pots. One week old seedlings were transplanted as one seedling per pot and after three days the seedlings were treated with different doses $(\mathrm{C}=\mathrm{Control}, 1=P$. fluorescens $(10 \mathrm{ml})+\mathrm{N} 50,2=P$. fluorescens $(10 \mathrm{ml})+\mathrm{N} 100,3=P$. fluorescens $(20 \mathrm{ml})+\mathrm{N} 50,4=P$. fluorescens $(20$ $\mathrm{ml})+\mathrm{N} 100,5=B$. subtilis $(10 \mathrm{ml})+\mathrm{N} 50,6=B$. subtilis $(10 \mathrm{ml})+\mathrm{N} 100$, $7=B$. subtilis $(20 \mathrm{ml})+\mathrm{N} 50$ and $8=B$. subtilis $(20 \mathrm{ml})+\mathrm{N} 100)$.

Uninoculated plants served as control. The pots were arranged in a randomized block design and all the treatments were replicated thrice. The plants were lightly watered after inoculation and thereafter, whenever, required. The experiment was terminated 60 days after inoculation and different parameters were determined.

*Corresponding author: Ambreen Akhtar, Section of Plant Pathology and Nematology, Department of Botany, Aligarh Muslim University, Aligarh, India, E-mail: ambreen.qazi08@gmail.com

Received August 20, 2013; Accepted September 24, 2013; Published September 30, 2013

Citation: Akhtar A, Hisamuddin, Abbasi, Sharf R (2013) Study on Black Gram (Vigna mungo L.) Infected with Meloidogyne incognita under the Influence of Pseudomonas fluorescens, Bacillus subtilis and Urea. J Plant Pathol Microb 4: 202. doi:10.4172/2157-7471.1000202

Copyright: (C) 2013 Akhtar A, et al. This is an open-access article distributed under the terms of the Creative Commons Attribution License, which permits unrestricted use, distribution, and reproduction in any medium, provided the original author and source are credited. 
Citation: Akhtar A, Hisamuddin, Abbasi, Sharf R (2013) Study on Black Gram (Vigna mungo L.) Infected with Meloidogyne incognita under the Influence of Pseudomonas fluorescens, Bacillus subtilis and Urea. J Plant Pathol Microb 4: 202. doi:10.4172/2157-7471.1000202

\section{Culturing of nematodes}

In order to obtain sufficient number of second-stage juveniles of Meloidogyne incognita for the experiment, the population of the test nematode was developed from a single egg mass on brinjal plants grown in microplots, well ahead of the beginning of the experiment. The required numbers of freshly hatched second-stage juveniles were collected from this pure culture as per the requirement.

Nematode inoculum: In order to procure second stage juveniles of Meloidogyne incognita, egg masses were handpicked, with the help of sterilized forceps from heavily infested egg plant roots on which pure culture of the nematode was maintained. The brinjal roots with egg masses were rinsed with distilled water and placed in $10 \mathrm{~cm}$ diameter 15 mesh coarse sieves which covered with crossed layers of tissue paper. The sieves were placed on petridishes containing sufficient water so that their lower part remained partially submerged in water. To avoid evaporation of water the petridishes were kept covered with their lids and kept in an incubator running at $25^{\circ} \mathrm{C}$. After $24 \mathrm{~h}$ onwards secondstage juveniles were collected in the form of suspension and stored for later use, and fresh water was added. The number of juveniles was counted using counting dish. The amount of water in the suspension was so adjusted that $10 \mathrm{ml}$ of this suspension contained 1000 freshly hatched juveniles. The plants were inoculated by adding $20 \mathrm{ml}$ of suspension per pot [17].

\section{Bacterial inoculum (Pseudomonas fluorescens and Bacillus subtilis)}

The pure cultures of Pseudomonas fluorescens strain CHA0 and Bacillus subtilis strain Bs-5 obtained from IARI, New Delhi, were maintained on King's B agar [18] and nutrient agar [19] media, respectively. Both the cultures (P. fluorescens and B. subtilis) were prepared on the described media by standard procedures. The suspension of bacterial culture comprised of $109 \mathrm{CFU}$ ml-1for $B$. subtilis and $10^{6} \mathrm{CFU} \mathrm{ml}{ }^{-1}$ for $P$. fluorescens $\mathrm{sp}$. Two to three day old broth of both the bacterial cultures were used to give root dip treatment to the seedlings in the planting hole.

Urea $\left[\mathrm{Co}\left(\mathrm{NH}_{2}\right)_{2}\right]$ was used as fertilizer; where one gram urea was equivalent to $460 \mathrm{mg}$ of nitrogen [20]. N50 and N100 values were evaluated as 107.29 and $215.51 \mathrm{mg}$ urea/kg soil.

\section{Leghaemoglobin content}

The leghaemoglobin content, in fresh nodules was estimated following the method described by Sadasivam and Mannickam [21]. The reading was taken at 539 and $556 \mathrm{~nm}$ on spectrophotometer, against a reagent blank.

$$
\begin{aligned}
& \text { Lb concentration }(\mathrm{mM})=\frac{\mathrm{A}_{556}-\mathrm{A}_{539}}{23.4} \times 2 \mathrm{D} \\
& \mathrm{D}=\text { Initial dilution }
\end{aligned}
$$

\section{Protein content}

The seed and leaf protein content was estimated by adopting the methodology of Lowry et al. [22]. $50 \mathrm{mg}$ of oven dried black gram seeds and leaves were ground with the addition of $1 \mathrm{ml}$ of $5 \%$ trichloroacetic acid. The absorbance was read at $660 \mathrm{~nm}$ using spectrophotometer. The total protein content was calculated by comparing the absorbance of each sample with a calibration curve plotted by taking known graded concentration of bovin serum albumin.

Total chlorophyll content
Total chlorophyll content in fresh leaves was estimated by using the methodology of MacKinney [23]. 1 gm finely cut fresh leaves were ground to a fine paste using mortar and pestle after pouring $20 \mathrm{ml}$ of $80 \%$ acetone. The mixture was centrifuged at $5,000 \mathrm{rpm}$ for 5 minutes. The supernatant was collected and the absorbance was read at 645 and $663 \mathrm{~nm}$ against the blank on spectrophotometer. The total chlorophyll content present in the extract was calculated using the following equation:

$$
22.9\left(\mathrm{~A}_{645}\right)+8.02\left(\mathrm{~A}_{663}\right) \times \frac{\mathrm{V}}{1000 \times \mathrm{W}}
$$

$A=$ Absorbance at specific wavelength

$\mathrm{V}=$ Final volume of chlorophyll extract in $80 \%$ acetone

$\mathrm{W}=$ Fresh weight of tissue, used for extraction

\section{Nitrogenase activity}

The nitrogenase activity was assayed adopting the procedure of Hardy et al. [24]. The results were expressed in terms of $\mu$ moles ethylene formed/plant/hour.

\section{Statistical analysis}

The results were analysed statistically by the analysis of variance followed by least significant difference (LSD) at $\mathrm{p}=0.05$ [25]. Duncan's multiple test were applied for testing significant differences [26].

$$
\begin{aligned}
& 1=\text { Control } \\
& 2=\text { Pseudomonas fluorescens }(10 \\
& 3=P \text {. fluorescens }(10 \mathrm{ml})+\mathrm{N} 100 \\
& 4=P \text {. fluorescens }(20 \mathrm{ml})+\mathrm{N} 50 \\
& 5=P \text {. fluorescens }(20 \mathrm{ml})+\mathrm{N} 100 \\
& 6=\text { Bacillus subtilis }(10 \mathrm{ml})+\mathrm{N} 50 \\
& 7=B . \text { subtilis }(10 \mathrm{ml})+\mathrm{N} 100 \\
& 8=B . \text { subtilis }(20 \mathrm{ml})+\mathrm{N} 50 \\
& 9=B . \text { subtilis }(20 \mathrm{ml})+\mathrm{N} 100
\end{aligned}
$$$$
2=\text { Pseudomonas fluorescens }(10 \mathrm{ml})+\mathrm{N} 50
$$

\section{Result and Discussion}

The above experiment revealed the beneficial effects of different doses of plant growth promoting rhizobacteria on the growth of black gram and antagonistic to nematode. Nitrogenous fertilizer and bio-fertilizers had influenced significantly over the growth attributes, nodulation, leghaemoglobin content, total chlorophyll content, nitrogenase activity and protein content of leaves and seeds.

It was a three factor experiment analysis comprising of biofertilizers (Pseudomonas fluorescens, Bacillus subtilis), inorganic fertilizer (Urea) and nematode (M. incognita). The effect of both the bio-fertilizers and the nitrogenous fertilizer showed significant increase in different growth and biochemical parameters with and without nematode infestation at $\mathrm{P}=0.05$ level. The above experiment showed that the given optimal doses of bio and chemical fertilizer were most effective in the plant growth and suppression of root galls caused by $M$. incognita infection.

\section{Shoot and root length}

The data presented in table 1 revealed that the combined inoculation of $P$. fluorescens and N100 significantly increased shoot and root length 
Citation: Akhtar A, Hisamuddin, Abbasi, Sharf R (2013) Study on Black Gram (Vigna mungo L.) Infected with Meloidogyne incognita under the Influence of Pseudomonas fluorescens, Bacillus subtilis and Urea. J Plant Pathol Microb 4: 202. doi:10.4172/2157-7471.1000202

over the control as well as other treatments. The shoot length of the treated plants with bio and chemical fertilizers increased significantly except in the treatments 2, 6 and 7. In nematode inoculated treatments, the values showed significant differences except in 3 and 8 . Highest reduction was found in treatment 6 on comparing with control by $15.98 \%$ in the presence of $1000 \mathrm{~J}_{2}$. Maximum increase in shoot length was recorded in the treatment $5(36.76 \mathrm{~cm})$. Same finding was found by Shankar et al. [27] who reported that there was a significant increase in plant height, shoot and root weight and reduction in gall index due to the inoculation of $P$. aeruginosa in tomato plants. There was a significant increase in the root length but the treatment 6 showed non-significant result on inoculating the nematode by $10.51 \%$ over control due to lower dose of bioagents, $B$. subtilis.

Liu et al. [28] found suppression of the root-knot nematode, $M$. incognita on tomato by dual inoculation with arbuscular mycorrhizal fungi and plant growth promoting rhizobacteria. The plant height due to nematode infection were significantly increased in the presence of P. fluorescens [29]. Nitrogen fertilizer was helpful in increasing the biomass attributes of plant and reduced nematode population in root [30]. Tariq et al. [31] conducted in vitro test, and recorded that cell free culture filtrate of some strains showed nematicidal activity against $M$. javanica root-knot nematode by killing the second stage juveniles and by retarding the egg hatch some Pseudomonas aeruginosa strains also showed positive impact on plant growth by increasing the plant height and fresh shoot weight and were found to produce indole-acetic acid at varying degree in chilli.

\section{Number of nodules and nodular dry weight}

Maximum number of nodules was observed in the treatment 5 (14.33) due to the higher doses of bio and chemical fertilizers. Increase in nodule number and nodule dry weight was higher in the presence of $P$. fluorescens than B. subtilis. All the treatments showed significant increase except in the treatment 6 (without nematode inoculating plant). Roopa et al. [32] evaluated the effectiveness of PGPR and Rhizobium on nodulation and growth productivity in chickpea. Among nematode inoculated plants non-significant difference was noticed in the treatment 2 when compared with control (Table 1). In all the treatments significant increase in nodule weight was noticed. Maximum and minimum increased values were recorded in the treatments 5 and 6 , respectively. P. fluorescens and B. subtilis, the biocontrolling agents controlled the nematode by killing second stage juveniles activity [33]. Jaizme-Vega et al. [34] concluded the beneficial effect of dual inoculation of AMF and Bacillus sp. on papaya and improved results in terms of nematode infection. Infection by root-knot nematodes decreased the number of functional nodules either through inhibition in overall nodulation or premature conversion of functional nodules into nonfunctional ones due to nematode invasion [35]. Some rhizobacteria also released volatiles for promoting plant growth as reported by Phillips et al. [36]. Stirling and Sharma [37] reported that biocontrol agents not only reduced infectivity of nematodes, but also increased the number of rhizobial nodules on the root system. Inoculation of nematodes which ultimately led to the reduced production and supply of carbohydrates to the nodules to fix atmospheric nitrogen [38,39].

\section{Leghaemoglobin (Lb) content and nitrogenase activity}

From the above experiment it was revealed that variations occurred in the leghaemoglobin content and the nitrogenase activity. All the treatments showed significant increase on comparing with the control except in treatment 2 and 3 , where the increment was non-significant. Treatment $5(3.81 \mathrm{mg} / \mathrm{gm})$ showed significant highest value of $\mathrm{Lb}$ content on inoculating maximum dose of Pseudomonas fluorescens and nitrogen and lowest value recorded in treatment $6(3.14 \mathrm{mg} / \mathrm{g})$ which increased non significantly (Figure 1).

Bacillus subtilis treatment with nitrogenous fertilizer was significantly less effective than $P$. fluorescens treatments with urea. On nematode infestation, treatment 4,8 and 9 showed non-significant increment result. Nitrogenase activity was highly affected and significantly increased by the inoculation of bio and chemical fertilizer. The highest reduction was recorded in treatment 6 on nematode infestation (Figure 5). Chahal et al. [40] showed the maximum number of nodules and nitrogenase activity on applying Rhizobium with or without nematode infestation at various levels of iron. Bhat et al. [41] concluded that $M$. incognita caused adverse effect on the growth of black gram, nodule development, nitrogen content of shoot and root, leghaemoglobin, bacteroids and nitrogenase activity. Plant growth promoting rhizobacteria showed its beneficial effect on leghaemoglobin content.

\section{Chlorophyll content}

Chlorophyll content of black gram leaves was significantly higher on applying various doses of biofertilizers and inorganic fertilizer with and without nematode infestation. The highest and lowest increased values were recorded in the treatment 5 and 6 , respectively. On inoculating nematode, the chlorophyll content values decreased significantly, whereas increased significantly on applying the maximum doses of bio and chemical fertilizer. The chlorophyll content in the treatment 8 increased non-significantly on comparing with control in nematode inoculated plant (Figure 2). Karnwal [42] with the help of experiment showed beneficial and best plant growth promoting activity

\begin{tabular}{|c|c|c|c|c|c|c|c|c|}
\hline \multirow[t]{2}{*}{ Parameters/Treatments } & \multicolumn{2}{|c|}{ Shoot Length (cm) } & \multicolumn{2}{|c|}{ Root Length (cm) } & \multicolumn{2}{|c|}{ No. of Nodules per plant } & \multicolumn{2}{|c|}{ Nodule Dry Weight (g) per plant } \\
\hline & & $\begin{array}{l}\text { Nematode } \\
\text { infested } \\
(1,000 \mathrm{~J} 2)\end{array}$ & & $\begin{array}{l}\text { Nematode } \\
\text { infested } \\
(1,000 \mathrm{~J} 2)\end{array}$ & & $\begin{array}{l}\text { Nematode } \\
\text { infested } \\
(1,000 \mathrm{~J} 2)\end{array}$ & & $\begin{array}{l}\text { Nematode } \\
\text { infested } \\
(1,000 \mathrm{~J} 2)\end{array}$ \\
\hline 1 (Without nematode) & $27.53 \pm 0.38$ & $27.53 \pm 0.38$ & $6.66 \pm 0.14$ & $6.66 \pm 0.14$ & $4.33 \pm 0.33$ & $4.33 \pm 0.33$ & $0.02 \pm 0.003$ & $0.02 \pm 0.003$ \\
\hline 2 & *28.40 \pm 0.60 & $24.36 \pm 0.24$ & $8.73 \pm 0.27$ & $8.20 \pm 0.05$ & $6.66 \pm 0.33$ & *4.66 \pm 0.33 & $0.043 \pm 0.003$ & $0.03 \pm 0.003$ \\
\hline 3 & $29.46 \pm 0.31$ & *26.93 \pm 0.27 & $10.46 \pm 0.32$ & $9.16 \pm 0.08$ & $9.33 \pm 0.33$ & $6.66 \pm 0.33$ & $0.070 \pm 0.017$ & $0.05 \pm 0.01$ \\
\hline 4 & $33.10 \pm 0.60$ & $31.33 \pm 0.27$ & $12.13 \pm 0.14$ & $10.86 \pm 0.33$ & $9.66 \pm 0.33$ & $7.66 \pm 0.33$ & $0.110 \pm 0.005$ & $0.10 \pm 0.005$ \\
\hline 5 & $36.76 \pm 0.33$ & $34.36 \pm 0.28$ & $14.40 \pm 0.25$ & $13.13 \pm 0.14$ & $13.66 \pm 0.33$ & $10.33 \pm 0.33$ & $0.140 \pm 0.003$ & $0.12 \pm 0.01$ \\
\hline 6 & *27.86 \pm 0.33 & $23.13 \pm 0.26$ & $8.50 \pm 0.15$ & *7.36 \pm 0.12 & $* 5.00 \pm 0.57$ & $4.33 \pm 0.33$ & $0.030 \pm 0.01$ & $0.02 \pm 0.01$ \\
\hline 7 & *28.36 \pm 0.58 & $23.83 \pm 0.18$ & $9.46 \pm 0.27$ & $8.26 \pm 0.16$ & $7.66 \pm 0.33$ & $6.33 \pm 0.33$ & $0.046 \pm 0.005$ & $0.013 \pm 0.003$ \\
\hline 8 & $31.60 \pm 0.26$ & ${ }^{*} 28.73 \pm 0.20$ & $10.20 \pm 0.08$ & $9.60 \pm 0.05$ & $9.33 \pm 0.33$ & $7.33 \pm 0.33$ & $0.093 \pm 0.006$ & $0.07 \pm 0.005$ \\
\hline 9 & $32.61 \pm 0.16$ & $32.30 \pm 0.17$ & $12.20 \pm 0.37$ & $12.20 \pm 0.05$ & $12.33 \pm 0.33$ & $9.33 \pm 0.33$ & $0.133 \pm 0.003$ & $0.130 \pm 0.01$ \\
\hline S.E. & \pm 0.74 & \pm 0.73 & \pm 0.43 & \pm 0.40 & \pm 0.58 & \pm 0.40 & \pm 0.008 & \pm 0.009 \\
\hline LSD (0.05) & 1.56 & 1.54 & 0.91 & 0.84 & 1.22 & 0.84 & 0.01 & 0.01 \\
\hline
\end{tabular}

${ }^{*}$ Non-significant

Table 1: Effect of $P$. fluorescens, $B$. subtilis and urea on the growth attributes of Vigna mungo L. infested by M. incognita. 
Citation: Akhtar A, Hisamuddin, Abbasi, Sharf R (2013) Study on Black Gram (Vigna mungo L.) Infected with Meloidogyne incognita under the Influence of Pseudomonas fluorescens, Bacillus subtilis and Urea. J Plant Pathol Microb 4: 202. doi:10.4172/2157-7471.1000202

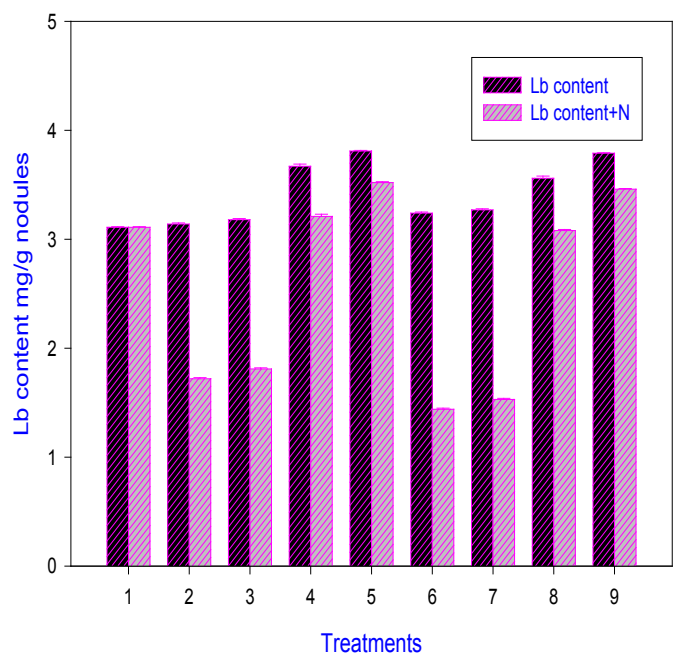

Figure 1: Variations occurred in the leghaemoglobin content and the nitrogenase activity.

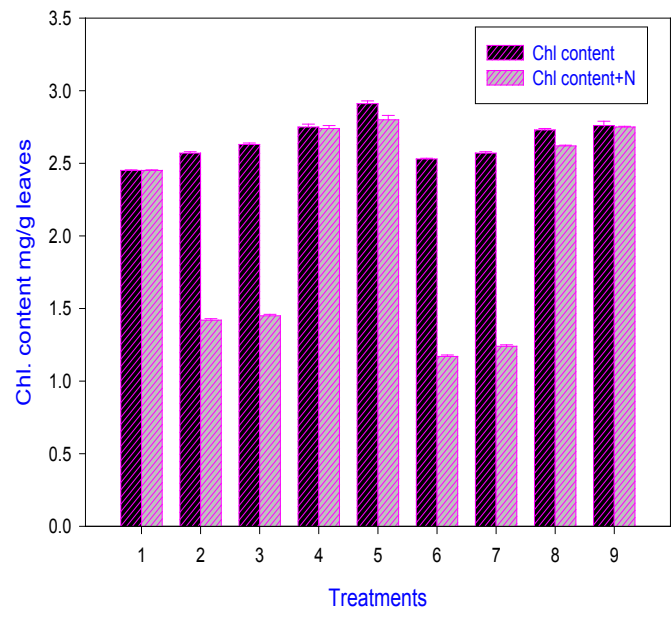

Figure 2: Chlorophyll content of black gram leaves.

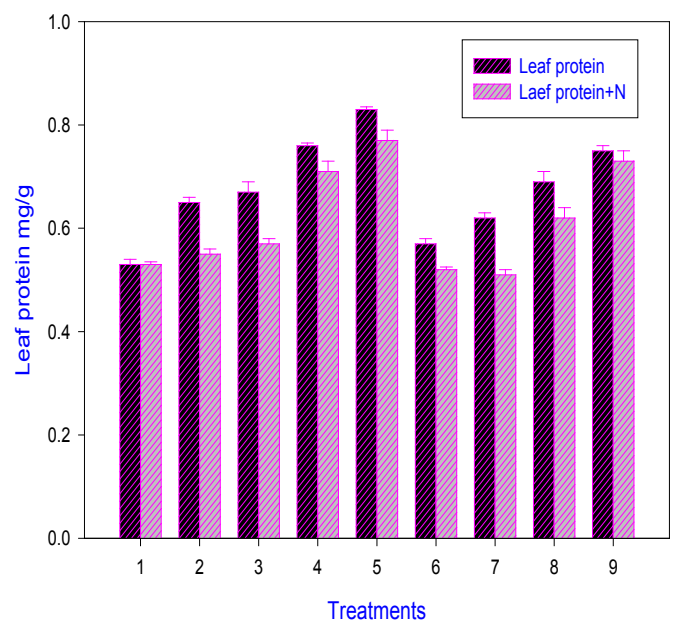

Figure 3: Data pertaining to leaves protein contents.

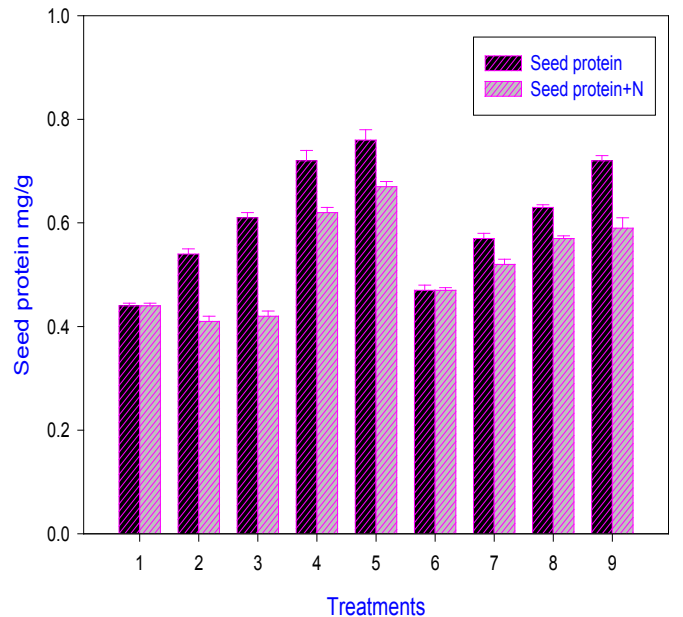

Figure 4: Data pertaining to seed protein contents.

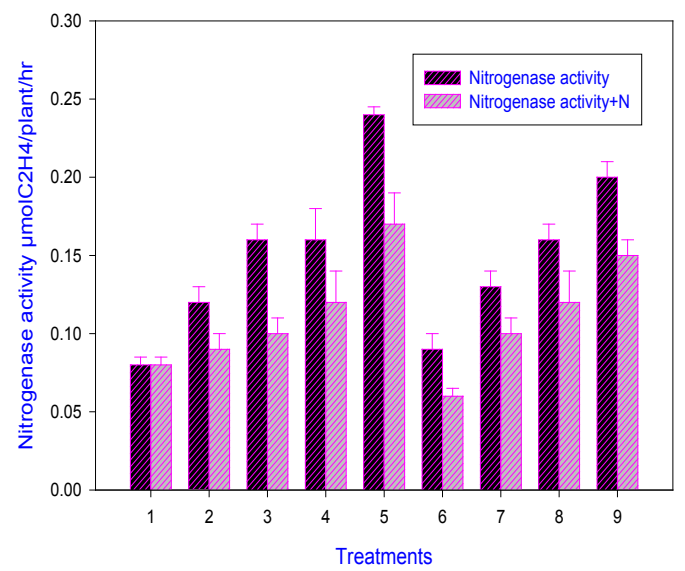

Figure 5: Nematode infestation on nitrogenous activity.

of $P$. fluorescens and $P$. aeruginosa due to the production of IAA. Plant growth promoting rhizobacteria significantly influence the chlorophyll content [43].

\section{Protein content in leaves and seeds}

Data pertaining to leaves and seed protein contents depicted that the treatments showed significant increase in protein content of leaf. The highest and lowest values were recorded in the treatment 5 and 6, but on nematode inoculation the treatment 6 recorded as non significant, and the treatment 7 showed significant decrease in leaf protein content. B. subtilis showed less significant results as compared to P. fluorescens with or without nematode inoculation (Figure 3). P. fluorescens and B. subtilis also helpful in solubilizing the insoluble phosphorus into solubilized form and make it available to the growth host plant $[44,45]$.

In seeds, the protein content, in all the treatments, significantly increased except in the treatment 6 where the increment was nonsignificant. The higher and lower values were recorded in treatment 5 $(0.67 \mathrm{mg} / \mathrm{g})$ and $2(0.41 \mathrm{mg} / \mathrm{g})$ (Figure 4$)$. PGPRs reduced pathogenic activity through induced systemic resistance. Some rhizobacteria (Bacillus spp.) have been found to produce lipopeptides, surfactins, bacillomycin $\mathrm{D}$, and fengycins which are secondary metabolites mainly 
Citation: Akhtar A, Hisamuddin, Abbasi, Sharf R (2013) Study on Black Gram (Vigna mungo L.) Infected with Meloidogyne incognita under the Influence of Pseudomonas fluorescens, Bacillus subtilis and Urea. J Plant Pathol Microb 4: 202. doi:10.4172/2157-7471.1000202

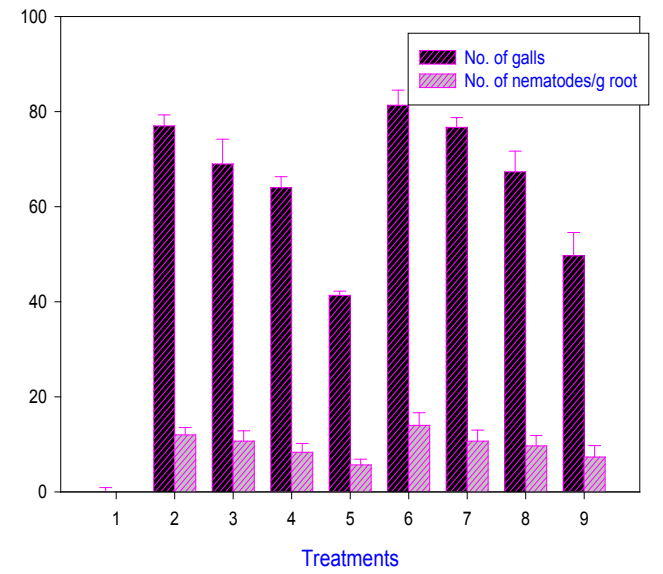

Figure 6: The number of galls per plant and the number of nematodes per gm root

with inhabitant pathogen activity [46]. In addition to some species of Pseudomonas, Bacillus reported to induce systemic resistance in plants against invading pathogens and antagonists to root-knot nematodes of meloidogyne spp. [47-51].

\section{Root galling and number of nematodes per gm root}

The number of galls per plant and the number of nematodes per gm root were decreased on increasing the doses of biocontrol agents. Maximum number of galls per plant, and nematodes per gm root was recorded in treatment 6 , and maximum reduction was recorded in the treatment 5 (Figure 6). Aino et al. [52] recorded protection of tomato from wilting disease by $P$. fluorescens colonization. Pseudomonas fluorescens produced an antibiotic 2, 4 diacetylphloroglucinol (DAPG) which decreased $M$. incognita egg hatching rate and increased crop yield reported by Meyer et al. (2009). Olowe [53] recorded that nitrogen resulted in better performance in plant yield and other biomass parameters and also reduced the $M$. incognita infection and galling. Combined treatment of NPK was significantly improved all the parameters. Sharoar et al. [54] found the significant effect of nitrogen fertilizer. Egunjobi and Olaitan [55] also revealed the reduction in galling by inorganic fertilizer application. Some authors also reported the great reduction in galling in other crops by NPK application [5660]. Rodriguez-Kabana (1986) [61] showed that on applying nitrogen fertilizer, the soil became more effective to suppress nematode populations due to excessive metabolizaion of $\mathrm{N}$ causing toxicity. On applying nitrogen to the soil, the phenol level increased as nematode declined [62].

$B$. subtilis and $B$. thuringiensis were considered the most used bacteria against plant parasitic nematodes [63], also recorded the reduced hatching of $M$. incognita in vitro by $B$. subtilis, $B$. thuringiensis and $B$. cereus on cowpea and mashbean. Various workers have reported about the suppressive effect of $P$. fluorescens and $B$. subtilis on $M$. incognita $[64,65]$. It was observed that in the presence of $P$. fluorescens and $B$. subtilis there was significant reduction in the severity of rootknot disease [29]. The mechanism of biocontrol activated due to production of antibiotic, siderophores and hydrogen cyanide [66].

From the results of above experiment it can be deduced that biofertilizers (P. fluorescens and B. subtilis) with nitrogenous fertilizer (Urea) could be uitilized for improving crop yield under field conditions.

\section{References}

1. Blaxter ML (2003) Nematoda: genes, genomes and the evolution of parasitism. Adv Parasitol 54: 101-195.

2. Hussey RS (1985) Host parasite relationships and associated physiologica changes. An Advanced Treatise on Meloidogyne Vol. 1: Biological control. North Carolina State University, Graphics, 143-153.

3. Trudgill DL, Blok VC (2001) Apomictic, polyphagous root-knot nematodes: exceptionally successful and damaging biotrophic root pathogens. Annu Rev Phytopathol 39: 53-77.

4. Abad P, Favery B, Rosso MN, Castagnone-Sereno P (2003) Root-knot nematode parasitism and host response: molecular basis of a sophisticated interaction. Mol Plant Pathol 4: 217-224.

5. Agrios GN (2005) Plant Pathology. (5thedn), Academic Press, USA.

6. Abad P, Gouzy J, Aury JM, Castagnone-Sereno P, Danchin EG, et al. (2008) Genome sequence of the metazoan plant-parasitic nematode Meloidogyne incognita. Nat Biotechnol 26: 909-915.

7. Kochhar SL (1998) Economic botany in the tropics. (2ndedn), 1-604.

8. Perveen K, Haseeb A, Shukla PK (1999) Effect of M. incognita and Fusarium udum on the disease development and growth of pigeonpea. Curr Nematol 10: $33-40$.

9. De RK, Ali SS, Dwivedi RP (2000) Interaction between Fusarium oxysporum $\mathrm{f}$ sp. lentis and M. javanica in lentil. Indian Phytopath 53: 353.

10. Mahapatra SN, Swain PK (2001) Interaction between M. incognita and Fusarium oxysporum on black gram. Annals of plant protection sciences 9 : 92-94.

11. Pavaraj M, Karthikairaj K, Rajan MK (2010) Effect of leaf extract of Ageratium conyzoides on the biochemical profile of black gram, Vigna mungo infected by root-knot nematode, M. incognita. J Biopest 3: 313-316.

12. Pal KK, Gardener BM (2006) Biological Control of Plant Pathogens. The Plant Health Instructor. lavicoli A, Boutet E, Buchala A, Métraux JP (2003) Induced systemic resistance in Arabidopsis thaliana in response to root inoculation with Pseudomonas fluorescens CHA0. Mol Plant Microbe Interact 16: 851-858.

13. Iavicoli A, Boutet E, Buchala A, Metraux JP (2003) Induced systemic resistance in Arabidopsis thaliana in response to root inoculation with Pseudomonas fluorescens CHA0. The American Phytopathological Society 16: 851-858.

14. Vance CP (2001) Symbiotic nitrogen fixation and phosphorus acquisition Plant nutrition in a world of declining renewable resources. Plant Physiol 127: 390-397.

15. CIAT (1989) Bean production problems in the tropics. (2ndedn), Cali, Colombia

16. Koenning SR, Barker KR (1985) Gnotobiotic techniques for plant parasitic nematodes. An Advanced Treatise on Meloidogyne Vol II: Methodology. Publication of the Department of Plant Pathology and the USAID.

17. Walters SA, Barker KR (1993) Comparison of Two Inoculum Preparation Methods for Rotylenchulus reniformis. J Nematol 25: 778-784.

18. King EO, Ward MK, Raney DE (1954) Two simple media for the demonstration of pyocyanin and fluorescin. J Lab Clin Med 44: 301-307.

19. Marshall RT (1993) Standard methods for the microbiological examination of dairy products, (16thedn), American Public Health Association, Washington, USA.

20. Lindquist JL, Evans SP, Shapiro CA, Knezevic SZ (2010). Effect of Nitrogen Addition and Weed Interference on Soil Nitrogen and Corn Nitrogen Nutrition. Weed Technol 24: 50-58.

21. Sadasivam S, Manickam A (1992) Biochemical Methods. (3rdedn), New Age International Publishers, New Delhi, India.

22. Lowry OH, Rosebrough NJ, Farr AL, Randall RJ (1951) Protein measurement with the Folin phenol reagent. J Biol Chem 193: 265-275.

23. Mackinney (1941) Absorption of light by chlorophyll solutions. J Biol Chem 140: 315-332.

24. Hardy RW, Holsten RD, Jackson EK, Burns RC (1968) The acetylene-ethylene assay for $\mathrm{n}(2)$ fixation: laboratory and field evaluation. Plant Physiol 43: 1185 1207. 
Citation: Akhtar A, Hisamuddin, Abbasi, Sharf R (2013) Study on Black Gram (Vigna mungo L.) Infected with Meloidogyne incognita under the Influence of Pseudomonas fluorescens, Bacillus subtilis and Urea. J Plant Pathol Microb 4: 202. doi:10.4172/2157-7471.1000202

25. Dospekhov BA (1984) Field experimentation. Statistical procedures. Mir Publishers, Moscow, Russia.

26. Duncan, DB (1955) Multiple range and multiple $F$ test. Biometrics 11: 1-42.

27. Shankar T, Pavaraj M, Umamaheswari K, Prabhu D, Baskaran S (2011) Effect of $P$. aeruginosa on root-knot nematode Meloidogyne incognita infecting tomato, Lycopersicum esculentum. Academic Journal of Entomology 4: 114117.

28. Liu R, Dai M, Wu X, Li M, Liu X (2012) Suppression of the root-knot nematode [Meloidogyne incognita (Kofoid \& White) Chitwood] on tomato by dual inoculation with arbuscular mycorrhizal fungi and plant growth-promoting rhizobacteria. Mycorrhiza 22: 289-296.

29. Akhtar A, Hisamuddin, Abbasi, Sharf R (2012) Antagonistic effects of Pseudomonas fluorescens and Bacillus subtilis on Meloidogyne incognita infecting Vigna mungo L. International Journal of Plant, Animal and Environmental Sciences 2: 55-63.

30. Ahmed SS, Kandil MM, Al-Ansi NA (1991) Effect of some fertilizers on development of Meloidogyne incognita and growth of cowpea. Ann Agric Sci 29: $1215-1220$

31. Tariq S, Khan R, Sultana V, Ara J, Ehteshamul-Haque S (2009) Utilization of endo root fluorescent Pseudomonas of chilli for the management of root diseases of chilli. Pak J Bot 41: 3191-3198.

32. Roopa B, Maya C, Makari HK (2012) Effect of different PGPR strains along with Rhizobium on nodulation and chickpea productivity. Asian J Exp Biol Sci 3: 424-426.

33. Li B, Xie GL, Soad A, Coosemans J (2005) Suppression of Meloidogyne javanica by antagonistic and plant growth-promoting rhizobacteria. J Zhejiang Univ Sci B 6: 496-501.

34. Jaizme-vega MC, Rodriguez-Romero AS, Nunez LAB (2006) Effect of the combined inoculation of arbuscular mycorrhizal fungi and plant growth promoting rhizobacteria on papaya (Carica papaya L.) infected with the rootknot nematode Meloidogyne incognita. Fruits 61: 151-162.

35. Khan MR, Khan MM, Anwer MA, Haque Z (2012) Laboratory and field performance of some soil bacteria used as seed treatments on Meloidogyne incognita in chickpea. Nematol medit 40: 143-151.

36. Phillips DA, Fox TC, King MD, Bhuvaneswari TV, Teuber LR (2004) Microbia products trigger amino acid exudation from plant roots. Plant Physiol 136: 2887-2894.

37. Stirling GR, Sharma RD (1990) Attachment of Pasteuria penetrans spores to the root knot nematodes Meloidogyne javanica in soil. Nematologica 36: 246252.

38. Minchin RL, Pate JS (1973) The carbon balance of a legume and the functional economy of its root nodules. J Exp Bot 24: 259-271.

39. Chahal PPK, Singh I, Chahal VPS (1983) Interaction between different population levels of Meloidogyne incognita and Rhizobium on green gram. J Res Pb Agri Univ 20: 399-402.

40. Chahal PPK, Chahal VPS, Kaur NP, Arora CL (1997) Effect of iron interaction with Rhizobium sp. and Meloidogyne incognita in relation to uptake of nitrogen, iron and zinc in mungbean. Nematol Meditt 25: 37-40.

41. Bhat MY, Fazal M, Hisamuddin (2009) Effect of Meloidogyne incognita race1 on the functioning of rhizobial nodules on black gram, Vigna mungo. Indian J Nematol 39: 59-64.

42. Karnwal A (2009) Production of indole acetic acid by fluorescent Pseudomonas in the presence of I-tryptophan and rice root exudates. J plant patho 91: 61-63.

43. El- Sherif AG, Refaei AR, El-Nagar ME, Salem HMM (2007) Integrated management of Meloidogyne incognita infecting eggplant by certain organic amendments, Bacillus thuringiensis and oxamyl with reference to N P K and total chlorophyll status. Plant Pathology Journal 6: 147-152.

44. Lipton DS, Blanchar RW, Blevins DG (1987) Citrate, Malate, and Succinate Concentration in Exudates from P-Sufficient and P-Stressed Medicago sativa L. Seedlings. Plant Physiol 85: 315-317.

45. Vassilev N, Vassileva M, Nikolaeva I (2006) Simultaneous P-solubilizing and biocontrol activity of microorganisms: potentials and future trends. Appl Microbiol Biotechnol 71: 137-144.

46. Chen XH, Vater J, Piel J, Franke P, Scholz R, et al. (2006) Structural and functional characterization of three polyketide synthase gene clusters in Bacillus amyloliquefaciens FZB 42. J Bacteriol 188: 4024-4036.

47. Zhou T, Paulitz TC (1994) Induced resistance in the biocontrol of Pythium aphanidermatum by Pseudomonas spp., on cucumber. J Phytopathol 142 : 51-63.

48. Wei G, Kloepper JW, Tuzun S (1996) Induced systemic resistance to encounter decreases and increased plant growth promoting bacteria under field conditions. Phytopathology 86: 221-224.

49. De Meyer G, Capieau K, Audenaert K, Buchala A, Métraux JP, et al. (1999) Nanogram amounts of salicylic acid produced by the rhizobacterium Pseudomonas aeruginosa 7NSK2 activate the systemic acquired resistance pathway in bean. Mol Plant Microbe Interact 12: 450-458.

50. Kloepper JW, Ryu CM, Zhang S (2004) Induced Systemic Resistance and Promotion of Plant Growth by Bacillus spp. Phytopathology 94: 1259-1266.

51. Kloepper JW, Ryu CM (2006) Bacterial endophytes as elicitors of induced systemic resistance. In: Schulz B, Boyle C, Siebern T (Eds.), Microbial Root Endophytes. Springer-Verlag, Heildelberg 33-51.

52. Aino M, Maekawa Y, Mayama S, Kato H (1997) Biocontrol of bacterial wilt of tomato by producing seedlings colonized withendophytic antagonistic pseudomonads. Plant Growth Promoting Rhizobacteria, Present status and future prospects, Nakanishi Printing 120-123.

53. Olowe TO (2012) The effect of fertilizer (NPK) on infestation of Meloidogyne incognita on cowpea, Vigna unguiculata. (L.). British Journal of Science 6 : 25-42.

54. Sharoar MG, Deb AC, Khaleque MA (2006) Effect of different doses of fertilizers ages on some root characters, nodules and yield components in blackgram (Vigna mungo L. Hepper). Asian J Plant Sci 5: 717-720.

55. Egunjobi OA, Olaitan JO (1986) Response of Meloidogyne incognita-infected cowpea to some agro- waste soil amendments. Nematropica 16: 33-43.

56. Coyne DL, Sahrawa KL, Plowright RA (2004) The influence of mineral fertilizer application and plant nutrition on plant parasitic nematodes in upland and low land rice in CoteDivoire and its implications in long-term Agricultural Research trials. Experimental Agriculture 40: 245-256.

57. Baimey G, Coyne D, Labuschagne N (2006) Effect of Fertilizer application on yam nematode (Scutellonema bradys) multiplication and consequen damage to yam (Dioscorea spp) under field and storage condition in Benin. International Journal of Pest Management 52: 63-70.

58. Dawar S, Irshad L, Kaki MJ (2007) Combined effectiveness of fertilizers in the control of root rot and root knot disease complex of mung bean and okra. International Journal of biology and Biotecnology 4: 83-88.

59. Okada H, Harada $H$ (2007) Effect of tillage and fertilizer on nematode communities in a Japanis soybeen field. Applied Soil Ecology 35: 582-590.

60. Hu G, Cao Z (2008) Nematode community structure under compost and chemical fertilizer management practice in the North China plain. Experimental Agriculture 44: 485-496.

61. Rodríguez-Kábana R (1986) Organic and inorganic nitrogen amendments to soil as nematode suppressants. J Nematol 18: 129-134.

62. Badra T, Khatta MM (1980) The effect of nitrogen fertilizers on the growth of olive and in relation to infestation of Rotylenchulus reniformis. Nematol Meditt 8: $67-72$.

63. Dawar S, Marium T, Zaki MJ (2008) Application of Bacillus species in contro of Meloidogyne javanica (Treub) chitwood on cowpea and mashbean. Pak J Bot 40: 439-444.

64. Eapen SJ, Ramana KV, Sharma YR (1997) Evaluation of Pseudomonas fluorescens isolates for control of Meloidogyne incognita in black pepper (Piper nigrum L.). In: Edison S, Ramana KV, Sasikumar B, Nirmala Babu K, Eapen SJ, (eds.). Biotechnology of Spices, Medicinal and Aromatic Plants. Indian Society for Spices, Calicut, India.

65. Khan MR, Akram M (2000) Effects of certain antagonistic fungi and rhizobacteria on wilt disease complex of tomato caused by Meloidogyne incognita and Fusarium oxysporum f. sp. lycopersici. Nematol Medit 28: 139_ 144.

66. Weller DM, Thomashow LS (1993) Use of rhizobacteria for biocontrol. Curr Opin Biotechnol 4: 306-311. 